
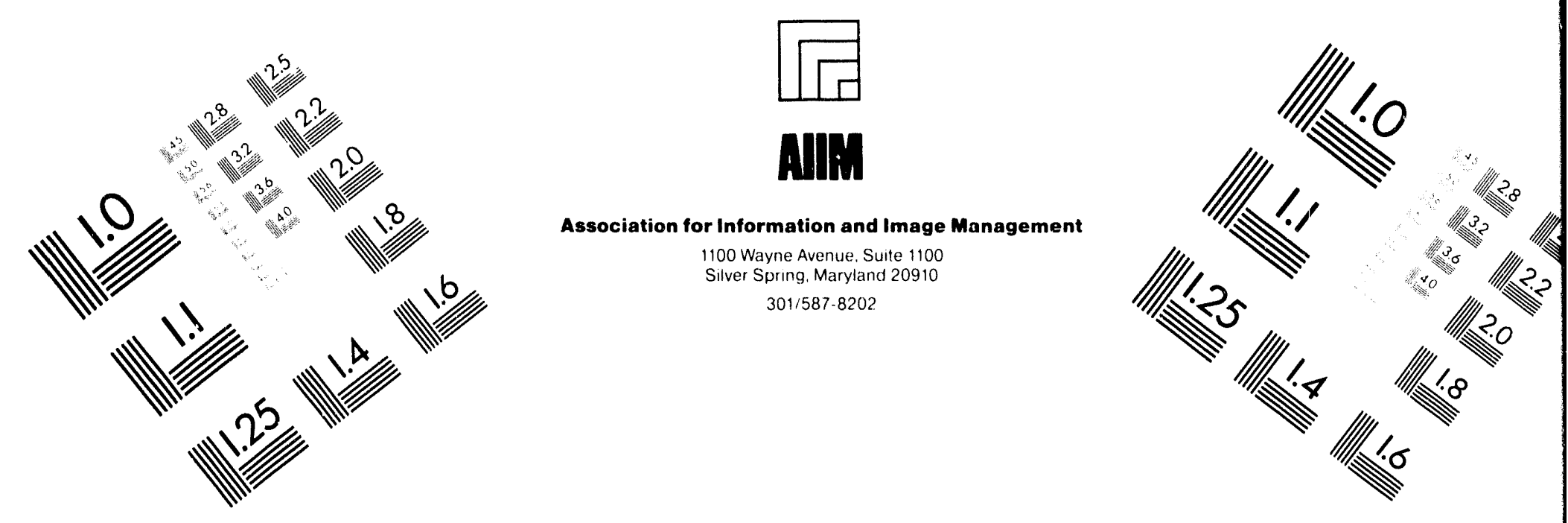

\title{
Centimeter
}

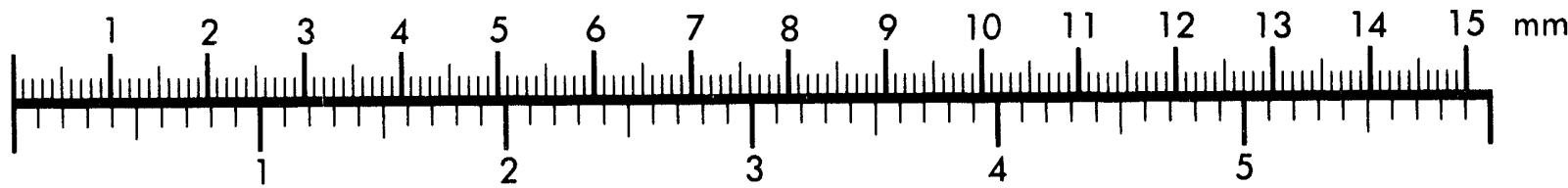
Inches
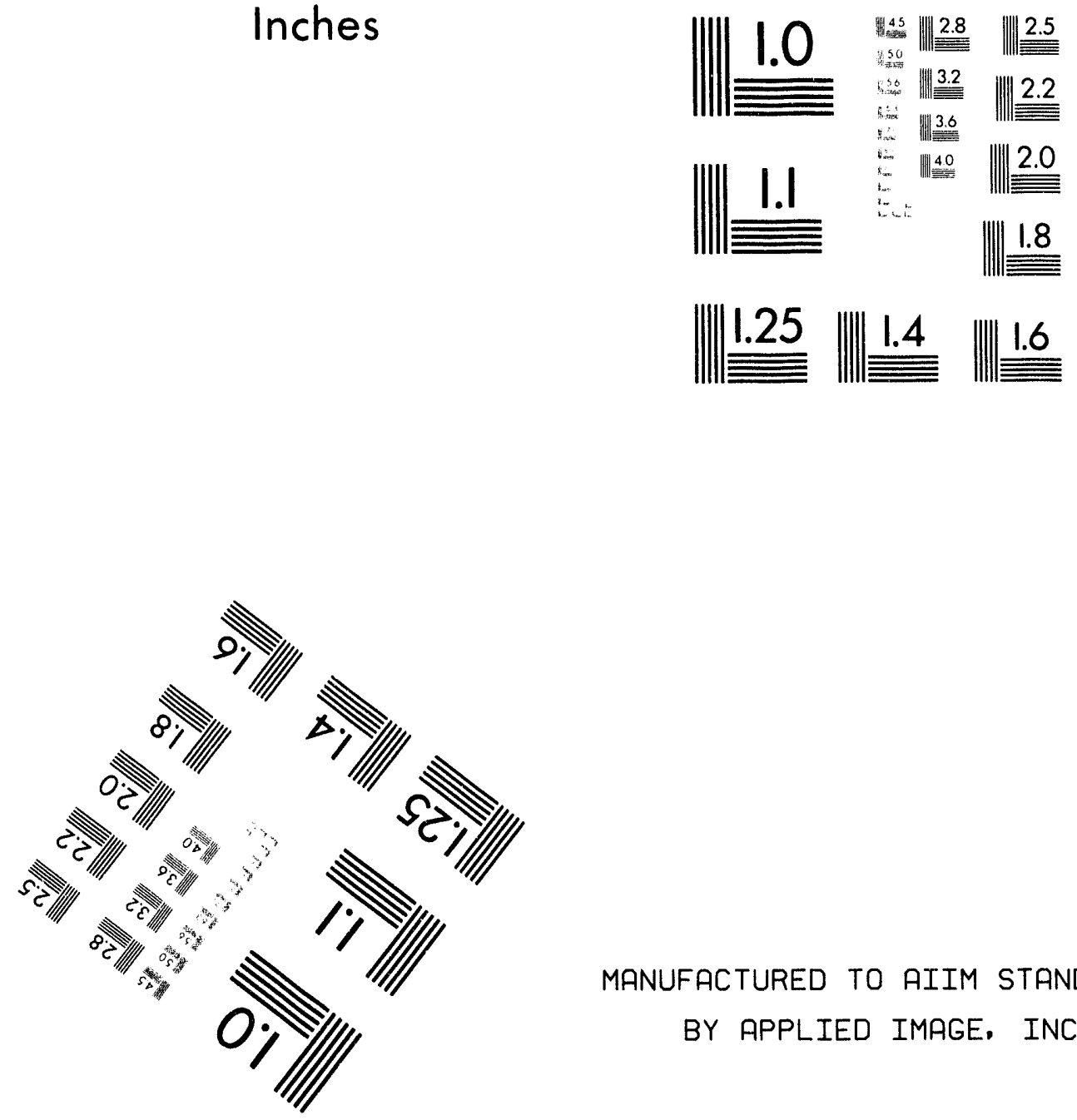

MANUFACTURED TO AIIM STANDARDS

BY APPLIED IMAGE, INC.

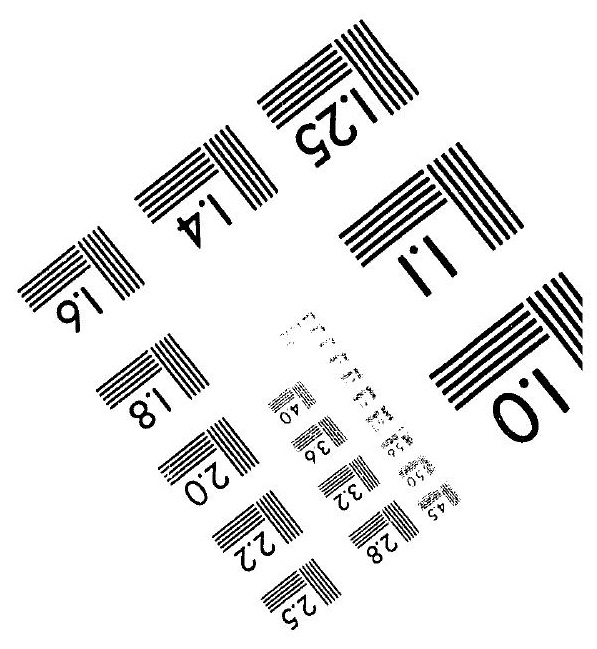



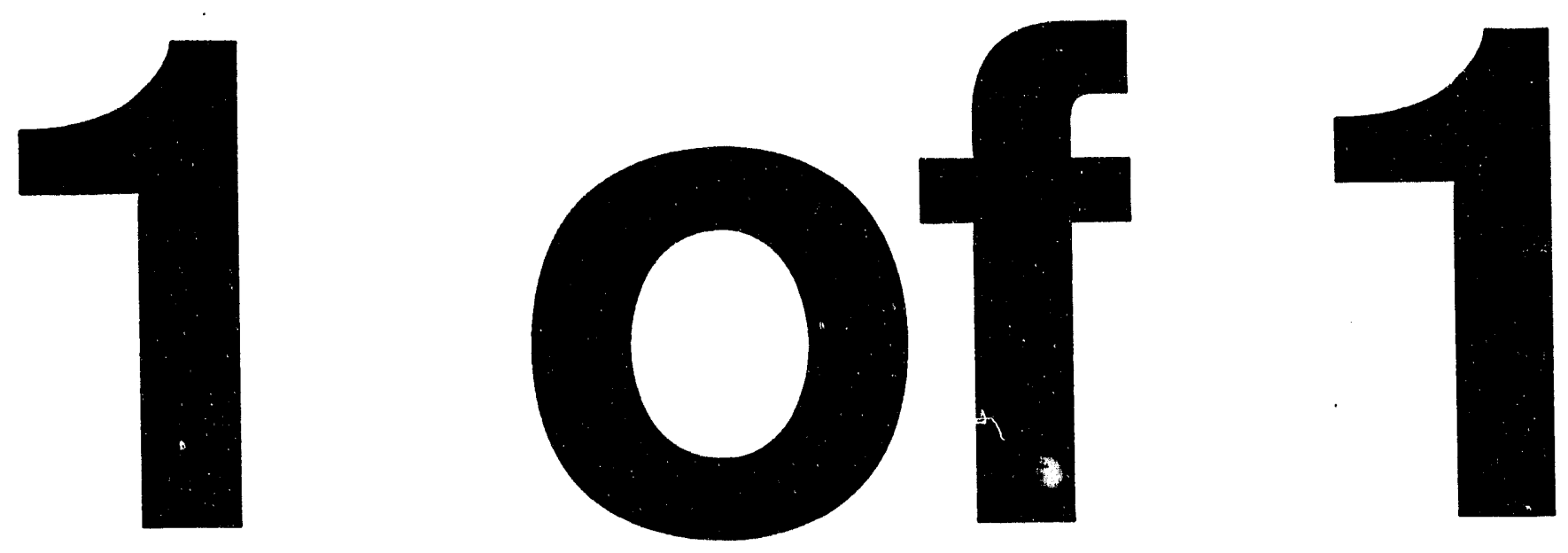


\title{
Canf-9408/2--2

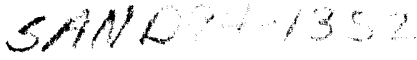

\section{THE DOE SOLAR THERMAL ELECTRIC PROGRAM*}

\author{
Thomas R. Mancini \\ Sandia National Laboratories \\ P. O. Box 5800, MS 0703 \\ Albuquerque, NM 87185
}

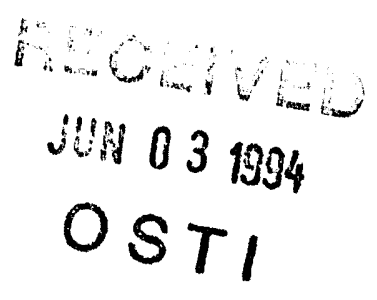

\begin{abstract}
The Department of Energy's Solar Thermal Electric Program is managed by the Solar Thermal and Biomass Power Division, which is part of the Office of Utility Technclogies. The focus of the Program is to commercialize solar electric technologies. In this regard, three major projects are currently being pursued in trough, central receiver, and dish/Stirling electric power generation. This paper describes these three projects and the activities at the National Laboratories that support them.
\end{abstract}

\section{INTRODUCTION}

The objective of the Solar Thermal Electric Program is to help industry to develop commercial solar-electric generation systems by the year 2000 [1]. The goal is for these systems to produce power expanding the mix of U.S. electrical power generation systems, as well as to provide commercial systems for export. The Program is involved in three cost-shared projects: the Development of Improved Operating and Maintenance Methods for Solar Thermal Power Plants [2, 3] for the trough-electric power plants in the Mojave Dessert of Southern California; the Solar 2 Project $[4,5]$ to build and demonstrate current power tower technology; and several cost-shared activities to develop modular dish/Stirling power systems [6, 7]. These three projects represent three different types of solar thermal electric technology, which are at three different levels of technical and commercial maturity. In this paper, I describe these three projects and the support activities provided by the DOE laboratories, Sandia and NREL.

\section{Q\&M IMPROVEMENT STUDY}

By far, the most mature of the three solar thermal electric technologies is represented by the nine trough Solar Electric Generating Systems (SEGS) operating in the Mojave Desert of Southern California. These nine plants deliver 354 MWe to Southern California Edison's power grid, which is approximately $90 \%$ of the solar electricity generated in the world today. An aerial photograph of the SEGS Plants at Kramer Junction, CA, is shown in Figure 1.

The SEGS plants utilize a total area of about $2.29 \times 10^{6} \mathrm{~m}^{2}$ of trough concentrators to heat a synthetic oil that flows through the receiver tube along the focus of the concentrators. The oil is heated to temperatures of 300 to $400^{\circ} \mathrm{C}$, depending on the plant. The hot oil is then circulated through a heat exchanger where it generates steam that powers a conventional Rankine cycle turbine generator. When solar heat is not available natural gas can be burned to generate peaking power. The SEGS plants were built by LUZ International Limited and are owned by private investors.

One of the major challenges facing SEGS is the reduction of operating and maintenance (O\&M) costs. O\&M costs represent more than $25 \%$ of the electricity costs at SEGS. Reducing the O\&M costs would improve the economics of the SEGS plants and the ability to market future plants. Furthermore, since O\&M costs for the SEGS plants are expected to be similar to those of both power tower and dish/Stirling plants, a better understanding of these costs will benefit all three technologies. Through Sandia National Laboratories, the DOE has developed a 50:50 cost-shared

\footnotetext{
- This work was performed at Sandia National Laboratories with the sponsorship of the U. S. Department of Energy on Contract No. DE-ACO4-76DP00789. It is a work of the U. S. Government and not subject to copyright protection in the United States.
} 


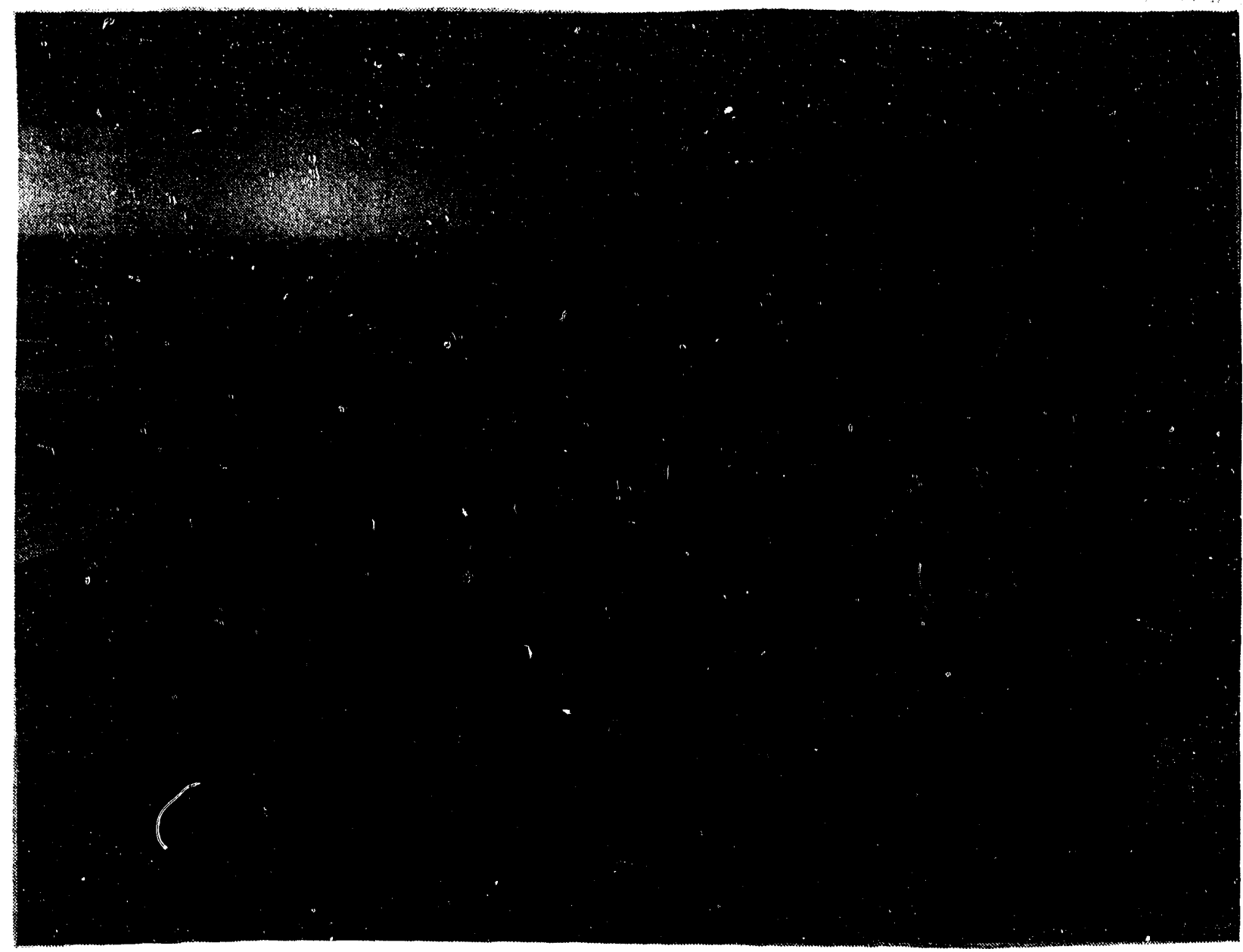

Figure 1. An Aerial View of the SEGS Plants at Kramer Junction, CA.

project with the KJC Operating Company to evaluate and reduce the O\&M costs associated with the SEGS plants III through VII.

\section{Characterization of O\&M Costs}

The first step in the process was to characterize the O\&M costs. This was done by carefully documenting the reasons for plant outages at SEGS III through SEGS VII during a 3-year period. The results of this study are shown in Table 1 below.

\section{Table 1}

Loss Contributions to SEGS Plants

\begin{tabular}{|l|c|}
\hline Loss Mechanism & Loss \% \\
\hline Forced Outages & 23.5 \\
\hline Degraded HCEs & 21.8 \\
\hline Scheduled Outages & 15.4 \\
\hline Field Alignment & 12.7 \\
\hline
\end{tabular}

Forced outages were caused by problems with the turbine bearings, the generator, valves, and solar field pumps. All of these problems were due to problems with early plants and the development of appropriate designs and components eliminated them in the later ones.

The second area that contributes to the losses at the SEGS plants is degraded and broken heat-collection elements' (HCEs). An initial finding from the study was that a significant annual cost was associated with replacing damaged receiver tubes. To reduce heat loss, these tubes are vacuum jacketed with a glass sleeve. The operating conditions at KJC resulted in a loss of vacuum as well as a number of broken tubes in some of the HCEs. Since the tubes are costly, the KJC Operating Company asked Sandia to test the receiver tubes with and without vacuum to help them 
trade off cost vs. performance loss. The results of testing at Sandia's National Solar Thermal Test Facility indicated that tubes in which the vacuum had been lost had almost twice the thermal losses of the original HCE while those with broken glass sleeves demonstrated up to 5 times greater thermal losses than tubes with a good vacuum, depending on wind speed. KJC is currently comparing the cost effectiveness of replacing receiver tubes that have lost vacuum but are not broken.

Scheduled outages account for the next highest level of loss contribution. It is important to note that lost solar time/energy is not the complete picture. The time of year is also important because down time during the winter months when less energy is collected is not as important as down time at summer solstice. Also, because of the payment schedule for the electricity generated by the plants, the value of energy is much higher during the summer peaks than during the winter time. Therefore, even though the scheduled outages appear to have a large effect on lost operations, this down time does not represent much lost revenue for KJC.

A number of additional issues is being addressed by the $\mathrm{KJC}$ Operating Company and Sandia. These include improved data collection and more efficient O\&M planning; improved Cermet receiver tube coatings, development of a new reflectometer to more easily determine when to wash the collector fields, and rotating joints to replace highmaintenance flexible hoses.

The performance of the SEGS plants has evolved from the initial performance demonstrated at SEGS I to the level represented by SEGS IX. The motivation for design has been for more cost-effective energy production. As a result, the systems have become larger (SEGS I was $30 \mathrm{MW}$ while SEGS IX is $80 \mathrm{MW}$ ) and are located near one another in an energy park so that they can share O\&M activities. The most recent plants are projected to operate at about $12 \%$ efficiency and are projected to produce electricity for 8 to 9 cents/kWhr with maintenance costs of about 2 cents/kWhr.
The purpose of the O\&M study is to help the KJC Operating Company to address the issues that are causing high $O \& M$ costs. The information learned from this study will also be useful to help us better understand the O\&M costs for power tower and dish/Stirling power plants.

\section{THE SOLAR 2 PRO JECT}

A second DOE commercialization project builds on the 10-Megaratt solar power tower experiment located nfar Earstow, CA. The Solar One Pilot Plant operated from 1982 until 1988 and proved the technical feasibility of solar power tower technology. Solar One used a water-filled receiver to produce steam and drive a turbine/generator. Energy was stored in an oil/rock thermocline storage tank. During its operation, Solar One produced more that 38 gigawatts of electrical power and was available more than $80 \%$ of the time, 95\% during its final year of operation [4]. Figure 2 is a photograph of the Solar One power plant.

In spite of its success, the Solar One Pilot Plant also demonstrated some important shortcomings: it had difficulty responding to cloud transients, the storage system was inefficient, and the direct water/steam system was difficult to operate. The next generation of power towers will utilize a molten salt system that addresses these problem areas.

Power towers utilize a field of mirrors, called heliostats, to reflect the solar energy on the thermal receiver that is mounted on top of a centrally-located tower. In order to keep the concentrated sunlight on the receiver at all times, each heliostat must track a position in the sky that is midway between the receiver and the sun as viewed from its location. The thermal energy collected is decoupled from the power generation by using a sodium nitrate salt as the working fluid. In the solar collection system, cold salt (melting point 220 C) is pumped out of a cold storage tank at a temperature of about $290 \mathrm{C}$ and through the thermal receiver where solar flux at 600 suns intensity heats the salt before delivering it to the hot storage tank at about $560 \mathrm{C}$. Electrical power is produced by removing the hot salt from the storage tank and passing it through a salt-to-steam heat exchanger where 
steam is generated and delivered to the turbine/ generator. Cold salt is returned to the cold storage tank. In this way, solar energy can be collected whenever the sun shines and power can be produced with a conventional turbine/ generator system from storage whenever it is needed.

A consortium of nine U. S. utilities led by Southern California Edison has entered into a cooperative agreement with the DOE to convert the Solar One Pilot Plant to use molten nitrate-salt technology. The objectives of the project are to reduce the economic risks of building the first-generation of power tower plants and to accelerate their commercial acceptance. This project, called Solar Two, will meet these two objectives if it can demonstrate the successful operation of a molten-salt system in a conventional power production mode of operation, that is not as an experiment. The six-year project will cost about 39 million dollars and is cost-shared 50:50 between the DOE and the utility consortium [5].
The conversion to Solar Two requires a number of changes to the existing plant. These include

- the removal of the existing rock/oil storage and thermal receiver;

- the design, fabrication, and installation of a molten-salt receiver, and hot and cold salt storage tanks;

- the increase of the heliostat area in the south field to provide a more uniform solar flux to the molten-salt receiver;

- the design and installation of a steam generator; and

- the upgrade of the master control system and turbine/generator.

The project is in its second year with construction and installation of the components scheduled to begin in the first quarter of 1995 and operation of the plant scheduled for the fourth quarter of 1995. Once the plant is operational, it will be operated in a continuous, power production mode for up to three years.

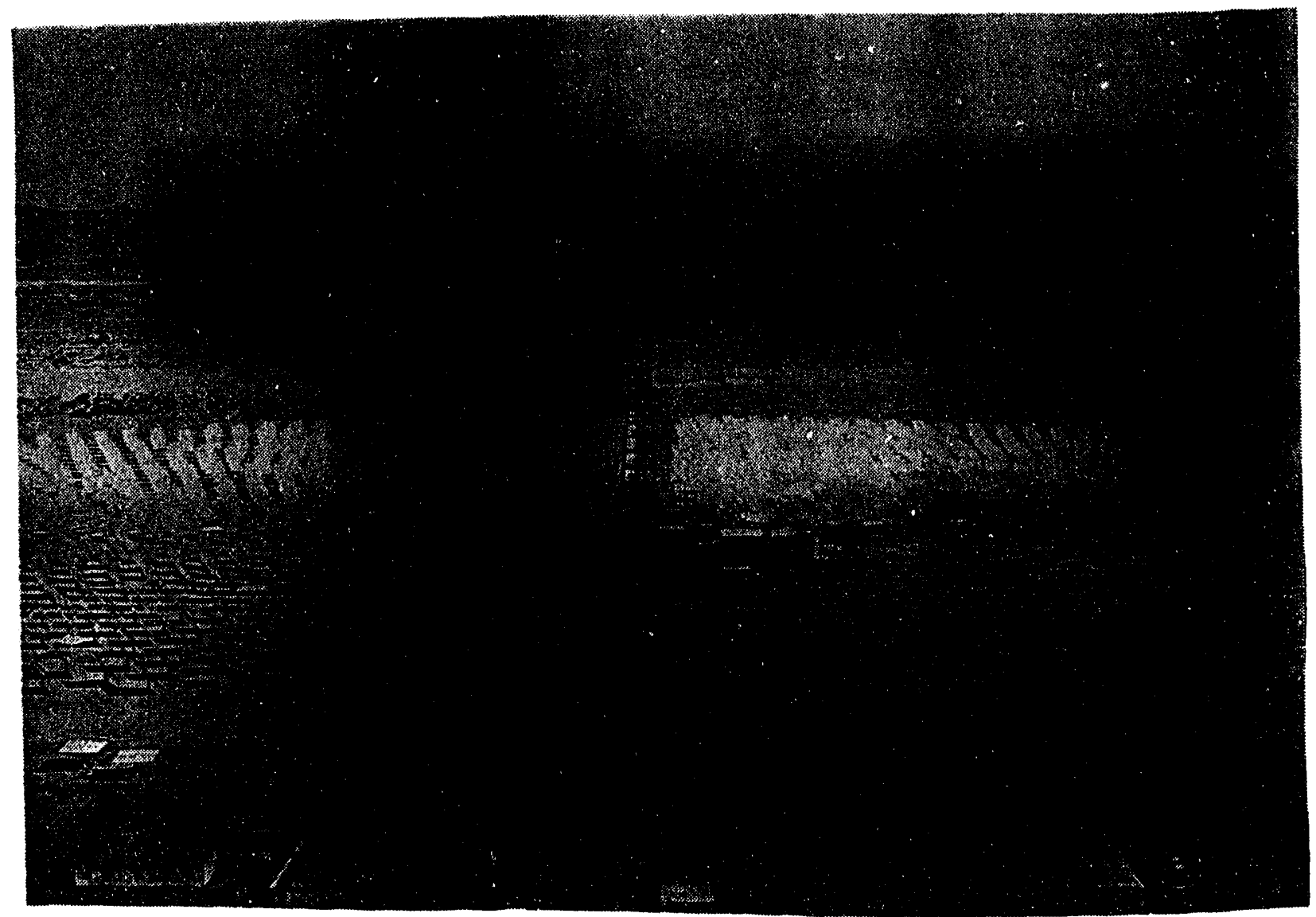

Figure 2. The Solar One Pilot Plant near Barstow, CA. 
Solar Two represents the first step in the commercialization of power tower technology. The next step would be to design and build several $100 \mathrm{MW}$ plants that would provide the necessary development and operational experience to take us to the final step -- the design and installation of $200 \mathrm{MW}$. power tower plants.

\section{DISH/ENGINE COMMERCIALIVATION}

There are currently three major DOE projects in the area of dish/engine commercialiazation: the Cummins Power Generation (CPG) Dish/ Stirling Project; the Utility-Scale JointVenture (USJV) Project; and an International Energy Agency (IEA) cooperative project to solarize a Brayton engine.

\section{CPGDish/Stirling Project}

The CPG Dish/Stirling Project is a 50:50 costshared project to develop a $7.5 \mathrm{~kW}$ powergeneration system for application in remote areas [6]. The project started in September of 1991 and will span a four-year period in which three generations of dish/Stirling technology are developed and tested. The \$14 million project is cost-shared equally by CPG and the DOE through Sandia National Laboratories.

The system comprises a solar concentrator, heat-pipe thermal receiver and a free-piston Stirling engine. The solar concentrator is a modification of the LaJet Energy Company LEC 460 design, which utilizes a geodesic space frame, a polar-axis drive, and stretchedmembrane polymer mirror facets. The heatpipe thermal receiver transfers the absorbed solar heat to the engine by evaporating sodium from backside of the receiver and condensing it on the tubes of the engine heater head. The receiver dssign also has the ability to provide heat $t \omega$ the engine by burning natural gas. Hybridization of the receiver allows the system to generate electricity on demand, not just when the sun shines. CPG recently changed their baseline engine for this system to the Clever Fellow's Innovative Consortium free-piston engine. This system with an earlier engine have operated in excess of 600 hours on sun. Figure 3 is a photograph of the CPG dish/Striling system.

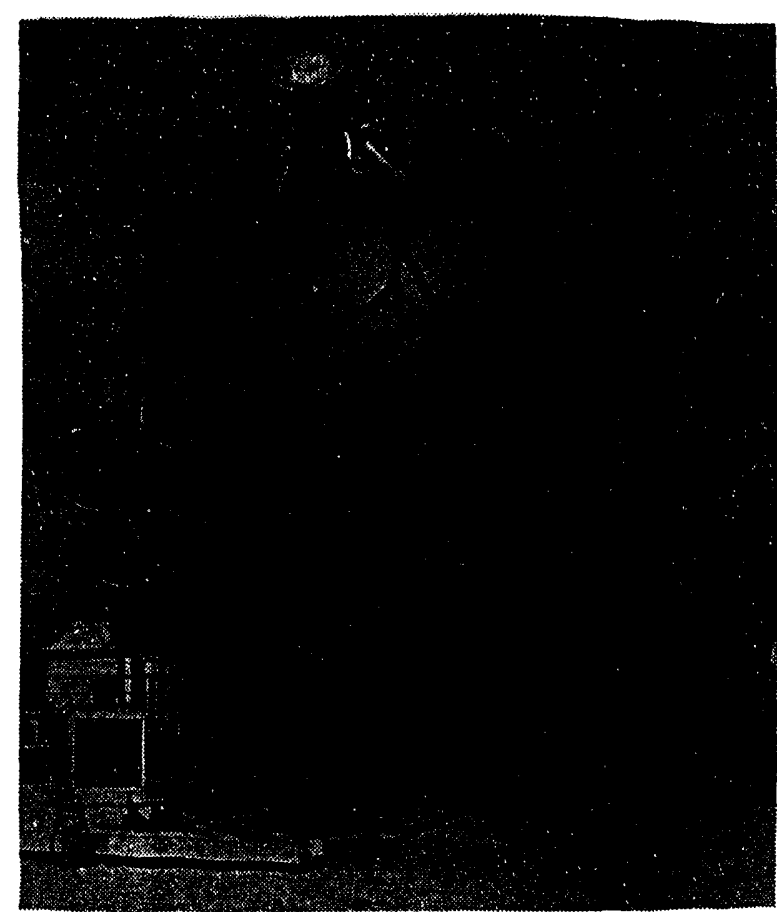

Figure 3. The CPG dish/Stirling System

\section{The USJV Project}

The objective of the USJV Program is to help industry to develop and market commercialscale dish/Stirling systems by the start of the twenty-first century. The five key elements of the program are

- The projects are directed at the commercialization of dish/engine systems by the year 2000 .

- There is a 50:50 cost share between the industry team and the DOE.

- The projects will last about five-years and comprise three phases. The last phase is the production, installation, and test of a $1 \mathrm{MWe}$ plant.

- Utility involvement in the projects is required in all three phases.

- The projects are industry led with support from the national laboratories.

Two projects were funded under the USJV Program in November 1993 and January 1994; one with Science Applications International Corporation's (SAIC) Energy Projects Division in Golden, $\mathrm{CO}$, and one with the Cummins Power Generation, Inc. (CPG) of Columbus, IN. SAIC and CPG have both been funded for Phases I and II of the project 
(3 years for SAIC and 4 years for CPG) at a total cost of about 18 million dollars each. Following the successful completion of the first two phases of the project, we will negotiate new contracts for Phase III. Phase III of the projects is estimated to cost from $\mathbf{1 5}$ to 20 million dollars for each [7].

SAIC leads a team comprising Stirling Thermal Motors (STM) and Detroit Diesel Corporation (DDC) of Ann Arbor, MI, and several utility partners. SAIC will provide the systems integration and the solar concentrator, which is a second-generation faceted stretched-membrane dish. STM will provide their kinematic Stirling engine and will lead the thermal receiver development activities. Detroit Diesel is responsible for designing the cold short block parts of the engine for mass production and for manufacture of the short block in later phases of the project.

The team that CPG has brought together consists of companies and individuals that have extensive experience in their fields. The subsystems and components under development and the responsible companies are: solar concentrator WGAssociates of Dallas, TX, and CPG; free piston Stirling engine -- Clever Fellows Innovative Consortium of Troy, NY; hybrid receiver -- Thermacore of Lancaster, PA.

Reference 8 is an excellent overview of the current status of dish/Stirling system development.

\section{Brayton Engine Solarization}

The DOE is also working to integrate a Brayton engine with a volumetric receiver designed by the German DLR in a cooperative International Energy Agency Project. In this project, the Northern Research Engineering Company is mating their Brayton engine with DLR's receiver for testing on Sandia's Test Bed Concentrator. This engine would also be available for a possible dish/engine system.

\section{SUMMARY}

The DOE is involved in a number of costshared projects whose objectives are the development of commercial solar thermal systems. Trough-electric systems are sufficiently mature to offer an alternative to conventional electric power production today. Solar power towers and dish/Stirling systems will be available in the next five years and will provide additional alternatives to fossil fuel power plants in the $21^{\text {st }}$ century.

\section{REFERENCES}

1. Solar Thermal Electric Five-Year Program Plan FY 1993 through 1997, Solar Thermal and Biomass Power Division, Office of Solar Energy Conversion, U. S. Department of Energy, Washington, DC.

2. Price, H., Kearney, D., Replogle, I., Update on the Performance and Operation of SEGS III - VII," Solar Engineering 1990, The 12th Annual ASME International Solar Energy Conference, Miami, FL, April 1-4, 1990, ISBN 0-79180472-0.

3. Miller, R., "Operation and Maintenance Cost Reduction at Solar Thermal Power Plants," Proceedings of the 6th International Symposium on Solar Thermal Concentrating Technologies, Mojacar, Spain, September 28 - October 2, 1992, ISBN 84-7834-163-3.

4. Radosevich, L. G. "Final Report on the Power Production Phase of the 1- MWe Solar Thermal Central Receiver Pilot Plant," SAND87-8022, Sandia National Laboratories, Livermore, CA, March 1988.

5. "Tuday's Solar Power Tower," SAND912018, Sandia National Laboratories, Albuquerque, NM, 1991.

6. Bean, J.R., R.B. Diver, "Performance of the CPG 7.5 kWe Dish Stirling System," 28th IECEC, August 8-13, 1993, pp. 2.627 2.632 .

7. Gallup, D. R., and T. R. Mancini, "The Utility-Scale Joint-Venture Program," 29th IECEC, August 7-12, 1994, Monterey, CA.

8. Stine W. B, and Diver, R. B., A Compendium of Solar Dish/Stirling Technology, SAND 93-7026 Sandia National Laboratories, Albuquerque, NM, January 1994. 


\section{DISCLAIMER}

This report was prepared as an account of work sponsored by an agency of the United States Government. Neither the United States Government nor any agency thereof, nor any of their employees, makes any warranty, express or implied, or assumes any legal liability or responsibility for the accuracy, completeness, or usefulness of any information, apparatus, product, or process disclosed, or represents that its use would not infringe privately owned rights. Reference herein to any specific commercial product, process, or service by trade name, trademark, manufacturer, or otherwise does not necessarily constitute or imply its endorsement, recommendation, or favoring by the United States Government or any agency thereof. The views and opinions of authors expressed herein do not necessarily state or reflect those of the United States Government or any agency thereof. 

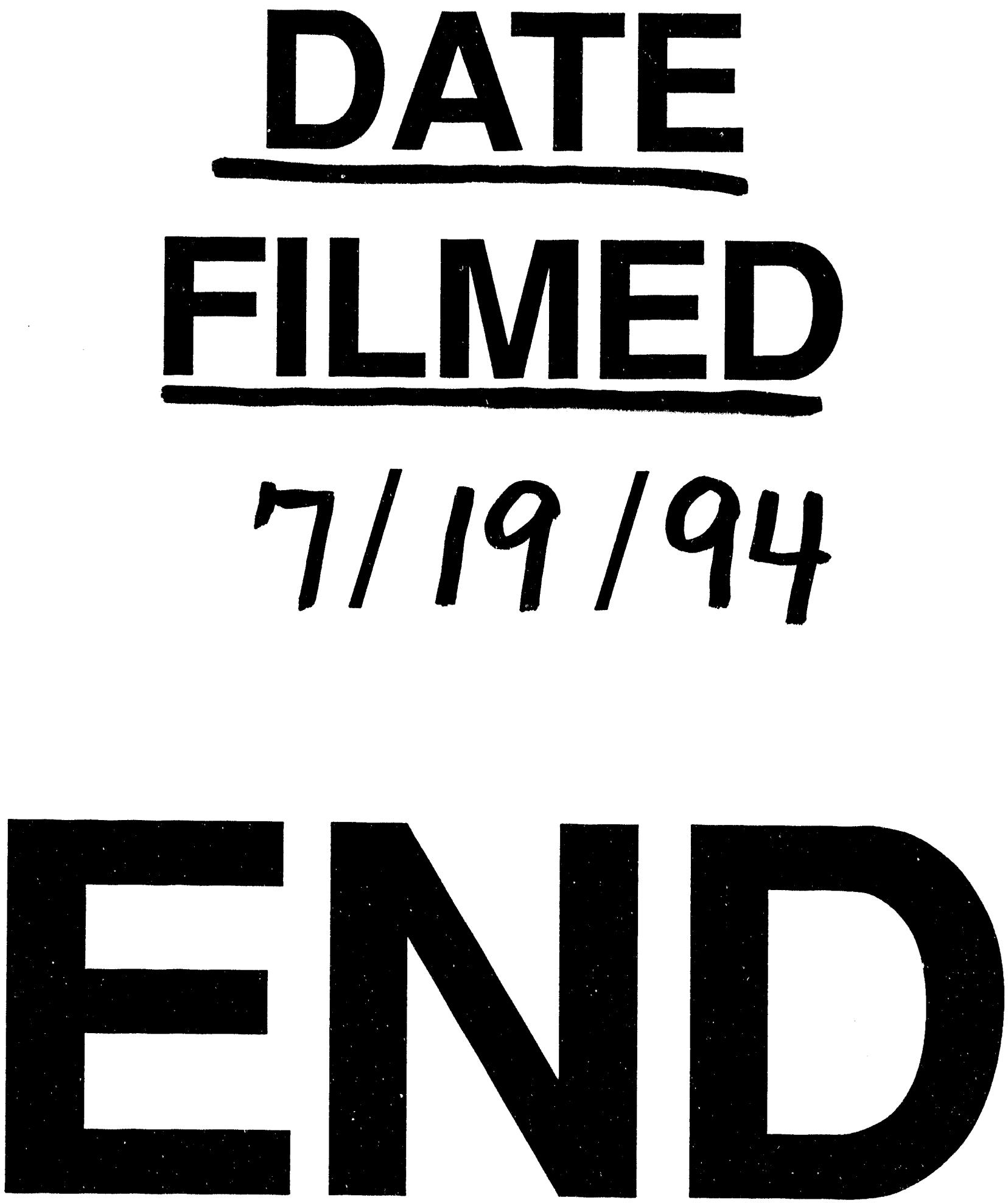
$I$ 